\title{
Fibroblast growth factor-4 maintains cellular viability while enhancing osteogenic differentiation of stem cell spheroids in part by regulating RUNX2 and BGLAP expression
}

\author{
JUWAN SON, JAE-YONG TAE, SAE KYUNG MIN, YOUNGKYUNG KO and JUN-BEOM PARK \\ Department of Periodontics, College of Medicine, The Catholic University of Korea, Seoul 06591, Republic of Korea
}

Received March 27, 2019; Accepted April 29, 2020

DOI: $10.3892 /$ etm.2020.8951

\begin{abstract}
Fibroblast growth factors (FGFs) are growth factors that were initially identified as proteins that stimulate fibroblast proliferation. The aim of the present study was to examine the effects of FGF-4 on the morphology, cellular viability and osteogenic differentiation of stem cell spheroids. Stem cell spheroids were generated using concave microwells in the presence of FGF-4 at concentrations of 0, 50, 100 and $200 \mathrm{ng} / \mathrm{ml}$. Cellular viability was qualitatively assessed by a fluorometric live/dead assay using a microscope and quantitatively determined by using Cell Counting Kit-8. Furthermore, alkaline phosphatase activity and calcium deposition were determined to assess osteogenic differentiation. Reverse transcription-quantitative PCR (RT-qPCR) was performed to evaluate the mRNA expression levels of Runt-related transcription factor 2 (RUNX2) and bone $\gamma$-carboxyglutamate protein (BGLAP). Spheroidal shapes were achieved in the microwells on day 1 and a significant increase in the spheroid diameter was observed in the $200 \mathrm{ng} / \mathrm{mlFGF}-4$ group compared with the control group on day $1(\mathrm{P}<0.05)$. The results regarding viability using Cell Counting Kit-8 in the presence of FGF-4 at 50,100 and $200 \mathrm{ng} / \mathrm{ml}$ at day 1 were $98.0 \pm 2.5,106.2 \pm 17.6$ and $99.5 \pm 6.0 \%$, respectively, when normalized to the control group $(\mathrm{P}>0.05)$. Furthermore, the alkaline phosphatase activity was significantly elevated in the $200 \mathrm{ng} / \mathrm{ml}$ group, when compared with the control group. The RT-qPCR results demonstrated that the mRNA expression levels of RUNX2 and BGLAP were significantly increased at $200 \mathrm{ng} / \mathrm{ml}$. Therefore, the present results suggested that the application of FGF-4 maintained cellular viability while enhancing the osteogenic differentiation of stem cell spheroids, at least partially by regulating RUNX2 and BGLAP expression levels.
\end{abstract}

Correspondence to: Professor Jun-Beom Park, Department of Periodontics, College of Medicine, The Catholic University of Korea, 222 Banpo-daero, Seoul 06591, Republic of Korea E-mail: jbassoonis@yahoo.co.kr

Key words: cell survival, cell differentiation, cellular spheroids, fibroblast growth factors, gingival, osteogenesis, stem cells

\section{Introduction}

Fibroblast growth factors (FGFs) are autocrine and paracrine growth factors that were initially identified as proteins and are able to stimulate fibroblast proliferation (1). However, previous studies have reported that, by binding to FGF receptors, FGFs are involved in multiple biological processes, including cellular proliferation, differentiation and tissue regeneration (2). Furthermore, FGFs have been applied to wounded tissues to examine its regenerative capability and results have revealed its healing potential (3). In this context, there have been several studies identifying the effect of FGFs on different types of stem cells $(4,5)$; however, the role of FGFs remains elusive due to varied and contradictive results. It is speculated that FGFs have different effects depending on the developmental stages of stem cells and their origins (6).

FGF-4 is a member of the FGF family and is a highly mitogenic protein encoded by the FGF-4 gene. Similar to other members of the FGF family, with a high affinity to its receptor, FGF-4 affects the proliferation, differentiation and migration of numerous types of cell (7). Furthermore, FGF-4 has been tested for the clinical treatment of angina (8). FGF-4 gene therapy using adenoviral vector has also been applied for the treatment of chronic ischemic heart disease (9). In addition, FGF-4 has been reported to enhance cell survival following ionization radiation (10). A previous study examining the effect of FGF-4 on human bone marrow cells have indicated that it stimulates cell proliferation in a dose-dependent manner (11). However, the precise effects of FGF-4 on different types of stem cells are yet to be established.

Dental stem cells, including gingiva-derived stem cells, are considered to be promising candidates for restoring lost periodontal tissue (12). Furthermore, based on previous studies, FGF-4 may promote the proliferation of mesenchymal stem cells $(11,13)$. It has also been reported that a 3 -dimensional (3D) culture system may enhance the understanding of cell proliferation and differentiation in normal and pathologic environments (14). In addition, features of mesenchymal stem cells under a 3D system may be different from the 2D culture system (15), and the 3D spheroid system may be applied as a tool for tissue regeneration (16).

Therefore, it was hypothesized that the addition of FGF-4 may have specific effects on the viability and osteogenic differentiation of mesenchymal stem cells. Thus, the aim of 
the present study was to examine the effects of FGF-4 on the morphology, viability and osteogenesis of stem cell spheroids composed of gingiva-derived stem cells.

\section{Materials and methods}

Fabrication of stem cell spheroids. To create stem cell spheroids, commercially available concave microwells (cat. no. H389600; StemFIT 3D; Micro FIT Co., Ltd.) with a $600-\mu \mathrm{m}$ well diameter were used. A total of $4.5 \times 10^{5}$ stem cells were loaded into each well and cultured to evaluate the cell response. Ethics approval was obtained from the Institutional Review Board of Seoul St. Mary's Hospital (approval no. KC17SESI0290) and the participant provided written informed consent according to the Declaration of Helsinki. All of the experiments were performed according to the relevant guidelines, which are also specified in the Declaration of Helsinki.

The tissue was obtained during the surgical procedures of dental implant second-stage surgery from a 75-year-old healthy female on August 2013. The epithelium of the gingival tissues was removed and cut into small pieces. Subsequently, digestion of the tissues was performed with $2 \mathrm{mg} / \mathrm{ml}$ collagenase IV (Sigma-Aldrich; Merck KGaA) and $1 \mathrm{mg} / \mathrm{ml}$ dispase (Sigma-Aldrich; Merck KGaA) (17). The cell suspension was filtered with a $70-\mu \mathrm{m}$ cell strainer (Thermo Fisher Scientific, Inc.) and seeded with $\alpha$-minimum essential medium (MEM; Gibco; Thermo Fisher Scientific, Inc.) containing 15\% fetal bovine serum (Gibco; Thermo Fisher Scientific,Inc.), $100 \mathrm{U} / \mathrm{ml}$ penicillin and $100 \mu \mathrm{g} / \mathrm{ml}$ streptomycin (Sigma-Aldrich; Merck KGaA). Cell spheroids were generated with gingiva-derived stem cells and were treated with FGF-4 (Prospec-Tany TechnoGene, Ltd.) at concentrations of 0, 50, 100 and $200 \mathrm{ng} / \mathrm{ml}$ at $37^{\circ} \mathrm{C}$ up to 14 days. The morphology of the cell spheroids was evaluated using an inverted light microscope (Leica DM IRM; Leica Microsystems GmbH). The diameter of the spheroids was measured by comparing the reference length on days 1, 3, 5 and 7 (14).

Determination of cellular viability. Stem cell spheroids were cultured in $\alpha$-MEM (Gibco; Thermo Fisher Scientific, Inc.) and the cellular viability was qualitatively analyzed using a commercially available kit (Live/Dead assay; Molecular Probes; Thermo Fisher Scientific, Inc.) on day 3 (18). The spheroids were washed twice with the growth media and incubated at room temperature for $30 \mathrm{~min}$ after applying $2 \mu \mathrm{l}$ of $50 \mathrm{mM}$ calcein acetoxymethyl ester and $4 \mu \mathrm{l}$ of $2 \mathrm{mM}$ ethidium homodimer-1 (Thermo Fisher Scientific, Inc.). Subsequently, stem cell spheroids were observed using a fluorescence microscope at x200 magnification (Axiovert 200; Zeiss AG). The assay was based on the principle that the intact cells exhibit green fluorescence [excitation (ex)/emission (em) $\sim 495 / \sim 515 \mathrm{~nm}]$, while cells with a compromised plasma membrane exhibit red fluorescence (ex/em 495/ 635 nm).

In addition, the number of viable cells was quantitatively examined using a commercially available kit (Cell Counting Kit-8; Dojindo Molecular Technologies, Inc.) on days 1, 3, 5 and 7 according to the manufacturer's instructions. The specific time-points were selected for analysis according to a previous study (19). Experiments were carried out in triplicate.
Flow cytometric analysis. The spheroids were detached to obtain a single-cell suspension prior to analysis. Stem cells were incubated with specific FITC-conjugated mouse monoclonal antibodies to human CD90 (cat. no. 11-0909-42; eBioscience; Thermo Fisher Scientific, Inc.) at $1 \mu \mathrm{g} / \mathrm{ml}$ concentration, which is considered a marker for a variety of stem cells at day 1 (20). Quantification of stained cells was performed using a flow cytometer (FACSCanto II; BD Biosciences) and the FACSDiva software (v8.0.3; BD Biosciences).

Evaluation of osteogenic differentiation. A total of $4.5 \times 10^{5}$ cells were grown in each well with osteogenic media comprising $\alpha$-MEM (Gibco; Thermo Fisher Scientific, Inc.), $38 \mu \mathrm{g} / \mathrm{ml}$ dexamethasone, $2 \mathrm{mg} / \mathrm{ml}$ glycerophosphate disodium salt hydrate, $10 \mathrm{mM}$ ascorbic acid 2-phosphate and $200 \mathrm{mM}$ L-glutamine on days 3, 7, 10 and 14. Alkaline phosphatase activity was evaluated using a commercially available assay kit (cat. no. K412-500; BioVision, Inc.). The absorbance was measured at $405 \mathrm{~nm}$ after mixing a $5 \mathrm{mM}$ p-nitrophenylphosphate substrate with cell lysates using assay buffer (cat. no. K412; BioVision, Inc.) and incubating it at $25^{\circ} \mathrm{C}$ for $40 \mathrm{~min}$. Comparisons were made between the groups, as the same number of cells was loaded in each group. The assays were performed three times. Stem cell spheroids were stained with $2 \%$ Alizarin Red S at room temperature for $30 \mathrm{~min}$ after fixing the cell spheroids with $4 \%$ paraformaldehyde at room temperature for $15 \mathrm{~min}$ and washing them with deionized water twice on day 14 (18). The degree of osteogenesis was evaluated by measuring the relative intensity of Alizarin red S staining using an inverted light microscope at x100 magnification (Leica DM IRM; Leica Microsystems $\mathrm{GmbH}$ ).

$m R N A$ quantification by reverse transcription-quantitative $P C R$ $(R T-q P C R)$. Total RNA was extracted from cell spheroids using TRIzol ${ }^{\circledR}$ reagent (Invitrogen; Thermo Fisher Scientific, Inc.) at day 8 (21,22). SuperScript II RTase (Invitrogen; Thermo Fisher Scientific, Inc.) was used for RT with total RNA according to the manufacturer's instructions at $42^{\circ} \mathrm{C}$ for $50 \mathrm{~min}$. Complementary DNA of mRNA was amplified using primer pairs as follows: Runt-related transcription factor 2 (RUNX2) forward, 5'-CAGTTCCCAAGCATTTCATCC-3' and reverse, 5'-AGG TGGCTGGATAGTGCATT-3'; bone $\gamma$-carboxyglutamate protein (BGLAP) forward, 5'-AATCCGGACTGTGACGA GTT-3' and reverse, 5'-CAGCAGAGCGACACCCTAGA-3'; and $\beta$-actin forward, 5'-AATGCTTCTAGGCGGACTATGA-3' and reverse, 5'-TTTCTGCGCAAGTTAGGTTTT-3'. RT-qPCR was performed on the StepOnePlus RT PCR system (Applied Biosystems; Thermo Fisher Scientific, Inc.) using a SYBR-Green PCR kit (Applied Biosystems; Thermo Fisher Scientific, Inc.) according to the manufacturer's instructions. The thermocycling conditions were as follows: Initial denaturation at $95^{\circ} \mathrm{C}$ for $10 \mathrm{~min}$, followed by 40 cycles of $95^{\circ} \mathrm{C}$ for $15 \mathrm{sec}$ and $30 \mathrm{sec}$ at $59^{\circ} \mathrm{C}$. The data were analyzed using the StepOne software v2.2.2 (Applied Biosystems; Thermo Fisher Scientific, Inc.). The expression of each RNA was normalized to an endogenous control $\beta$-actin and was calculated using the $2^{-\Delta \Delta \mathrm{Cq}}$ method (23). The experiments were performed three times.

Western blot analysis. Cells were lysed and extracted using lysis and extraction buffer (Pierce IP Lysis Buffer; cat. 


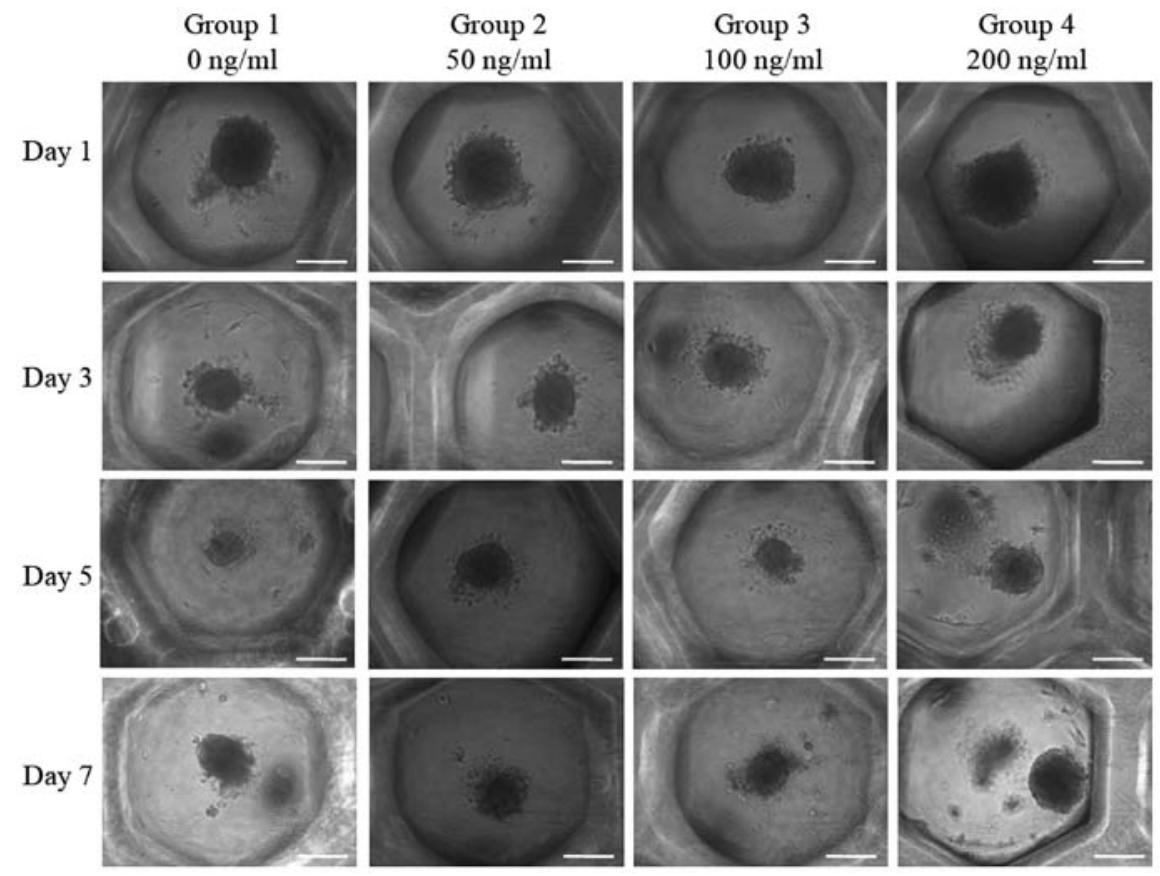

Figure 1. Commercially available concave microwells with $600-\mu \mathrm{m}$ diameter were used to generate stem cell spheroids. Representative images revealing the morphology of the stem-cell spheroids at days 1,3,5 and 7 are provided (scale bar, $200 \mu \mathrm{m}$ ).

no. 87787; Thermo Fisher Scientific, Inc.) according to the manufacturer's protocols on day 7 (24). Protein in the whole-cell lysates was quantified using the bicinchoninic acid assay (Thermo Fisher Scientific, Inc.). A total of $10 \mu \mathrm{g} / \mathrm{lane}$ of protein samples were loaded on a $7.5 \%$ gel for collagen I and loaded on a $10 \%$ gel for RUNX2 and GAPDH experiments, respectively and then transferred to polyvinylidene difluoride membranes (Immun-Blot ${ }^{\circledR}$; Bio-Rad Laboratories, Inc.) for immunoblotting. The membranes were blocked with 5\% skim milk for $1 \mathrm{~h}$ at room temperature. The membranes were incubated with the following primary antibodies overnight at $4^{\circ} \mathrm{C}$ : Anti-collagen I (1:500; cat. no. ab6308; Abcam), anti-RUNX2 antibody (1:200; cat. no. ab76956; Abcam) and anti-GAPDH antibody (1:2,000; cat. no. ab9485; Abcam). After washing with TBS-0.1\% Tween-20, membranes were incubated with horseradish peroxidase-conjugated secondary antibodies, goat anti-mouse immunoglobulin G (IgG; cat. no. ab205719; Abcam) and goat anti-rabbit IgG (cat. no. ab205718; Abcam) at $1: 10,000$ dilution for $2 \mathrm{~h}$ at room temperature. The immunoblot signals were visualized using horseradish peroxidase substrate (cat. no. WBKLS0100; Merck KGaA).

Statistical analysis. Values are expressed as the mean \pm standard deviation. A test of normality was performed to confirm the equality of variances in the samples. Differences among the groups were analyzed using one-way analysis of variance with Tukey's post-hoc test (SPSS 12 for Windows; IBM Corp.). $\mathrm{P}<0.05$ was considered to indicate a statistically significant difference.

\section{Results}

Formation of cell spheroids with human gingiva-derived stem cells. Spheroids were well formed in each microwell on day 1 (Fig. 1). Furthermore, no noticeable morphological

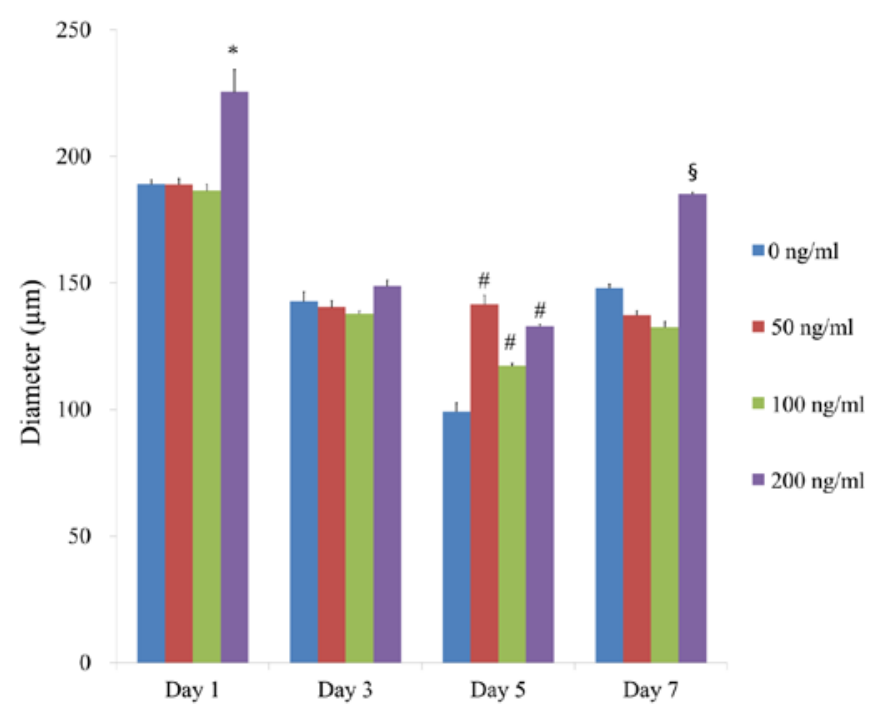

Figure 2. Diameter of the spheroids at days 1, 3, 5 and 7. Groups 1-4 were treated with fibroblast growth factor- 4 at $0,50,100$ and $200 \mathrm{ng} / \mathrm{ml}$, respectively. ${ }^{*} \mathrm{P}<0.05$ vs. control at day $1 ;{ }^{\#} \mathrm{P}<0.05$ vs. control at day $5 ;{ }^{\circledR} \mathrm{P}<0.05$ vs. control at day 7 .

changes of the cell spheroids were observed with the addition of FGF-4 at the concentrations of 50, 100 and $200 \mathrm{ng} / \mathrm{ml}$. Images revealing the morphology of the spheres of days 1,3,5 and 7 are presented in Fig. 1. It was indicated that there were no noticeable changes at the longer incubation times.

The average spheroid diameters at day $1,3,5$ and 7 in the presence of FGF-4 at 0, 50, 100 and $200 \mathrm{ng} / \mathrm{ml}$ were presented in Fig. 2. A statistically significant increase was identified with FGF-4 at $200 \mathrm{ng} / \mathrm{ml}$ compared with the control at day 1 $(\mathrm{P}<0.05)$. Addition of FGF-4 led to the increase of the diameter at 50,100 and $200 \mathrm{ng} / \mathrm{ml}$ compared with the control at day 5 $(\mathrm{P}<0.05)$. Furthermore, a statistically significant increase was 


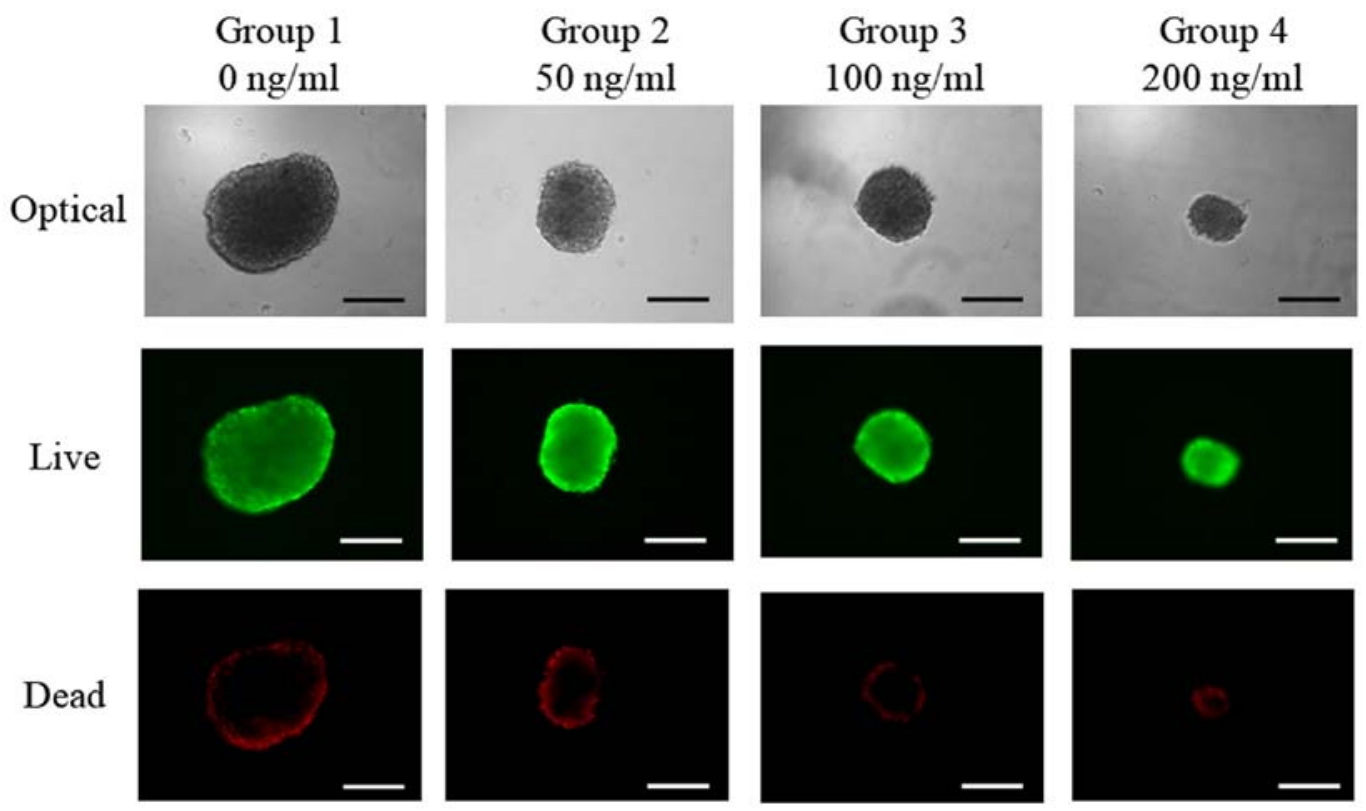

Figure 3. Cellular viability was qualitatively analyzed using a Live/Dead assay. Optical, live and dead cell images of stem cell spheroids at day 3 are provided (scale bar, $100 \mu \mathrm{m}$ ). Groups 1-4 were treated with fibroblast growth factor-4 at 0, 50, 100 and $200 \mathrm{ng} / \mathrm{ml}$, respectively.

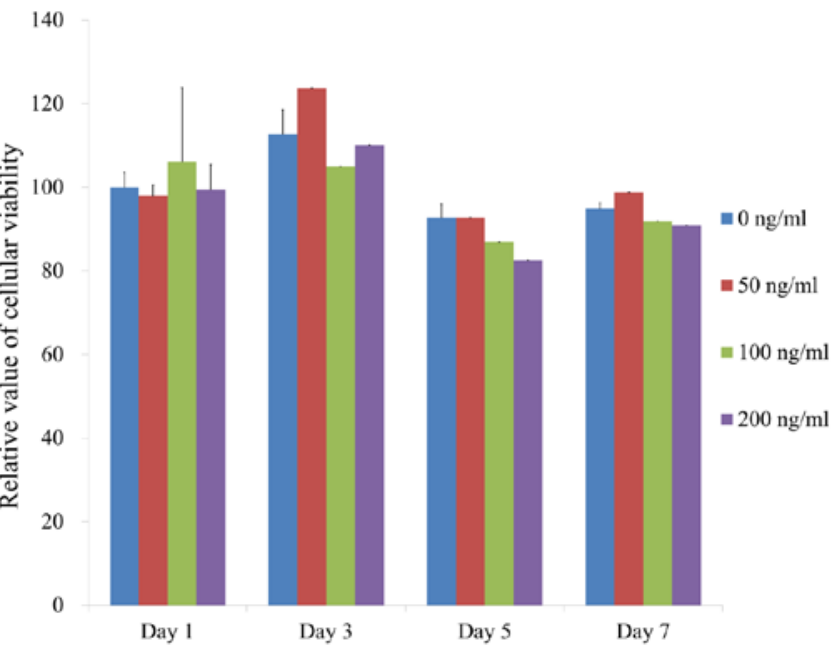

Figure 4. Cellular viability determined using a Cell Counting Kit-8 assay on days $1,3,5$ and 7 . The effect of FGF-4 at $0,50,100$ and $200 \mathrm{ng} / \mathrm{ml}$ at day 1 on the number of viable cells was quantified as $100.0 \pm 3.5,98.0 \pm 2.5,106.2 \pm 17.6$ and $99.5 \pm 6.0 \%$, respectively $(\mathrm{P}>0.05)$. Groups $1-4$ were treated with FGF-4 at $0,50,100$ and $200 \mathrm{ng} / \mathrm{ml}$, respectively. FGF-4, fibroblast growth factor-4.

demonstrated in the group treated with FGF-4 at $200 \mathrm{ng} / \mathrm{ml}$ compared with the control at day $7(\mathrm{P}<0.05)$.

Determination of cellular viability. Qualitative results regarding the viability of cell spheroids were obtained using a Live/Dead kit assay at day 3 (Fig. 3). In all cases, most of the cells in the cell spheroids emitted green fluorescence. Red fluorescence was partly seen on the boundary of the spheroids. Furthermore, the quantitative results for cellular viability on days 1, 3, 5 and 7 are provided in Fig. 4. The effect of FGF-4 at $0,50,100$ and $200 \mathrm{ng} / \mathrm{ml}$ at day 1 on the number of viable cells was quantified as $100.0 \pm 3.5,98.0 \pm 2.5,106.2 \pm 17.6$ and $99.5 \pm 6.0 \%$, respectively. The results indicated that there were no significant differences among the groups on day $1(\mathrm{P}>0.05)$.
Furthermore, no significant differences were identified between the groups with longer incubation times $(\mathrm{P}>0.05)$.

Expression of stem cell markers. The expression of the CD90 surface marker was observed on day 1 (Fig. 5); the percentages of CD90 were $88.1 \%$ for the untreated control $(0 \mathrm{ng} / \mathrm{ml}), 41.1 \%$ for the $50 \mathrm{ng} / \mathrm{ml}$ group, $64.7 \%$ for the $100 \mathrm{ng} / \mathrm{ml}$ group and $76.3 \%$ for the $200 \mathrm{ng} / \mathrm{ml}$ group.

Increase of alkaline phosphatase activity assay and Alizarin Red S staining with addition of FGF-4. The results of the alkaline phosphatase activity assay at days 3, 7, 10 and 14 are presented in Fig. 6. The relative value for alkaline phosphatase activity at day 7 for the groups treated with FGF-4 at 50, 100 and $200 \mathrm{ng} / \mathrm{ml}$ were $111.3 \pm 1.1,102.5 \pm 1.2$ and $106.2 \pm 3.3 \%$, respectively, when the control group was considered $100 \%$ $(100.0 \pm 2.3 \%)$. In addition, the group treated with FGF-4 at $200 \mathrm{ng} / \mathrm{ml}$ had a significantly higher value compared with that of the control group at day $7(\mathrm{P}<0.05)$.

The results of the Alizarin Red S staining assay to detect mineralization at day 14 are provided in Fig. 7A. It was observed that mineralized extracellular deposits were present in each group. Furthermore, the results of the quantitative analysis of Alizarin Red S staining indicated increasing trends with increasing concentrations of FGF-4, however, this was not statistically significant $(\mathrm{P}>0.05$; Fig. 7B).

Increaes of $m R N A$ expression by $R T-q P C R$ and protein expression by Western blot analysis. The results of the RT-qPCR analysis suggested that the mRNA expression of RUNX2 was $100.0 \pm 12.0,106.2 \pm 7.2,65.3 \pm 2.7$ and $224.6 \pm 17.1 \%$ for the groups treated with FGF-4 at $0,50,100$ and $200 \mathrm{ng} / \mathrm{ml}$, respectively. It was demonstrated that the application of $100 \mathrm{ng} / \mathrm{ml}$ FGF-4 decreased RUNX2 expression but $200 \mathrm{ng} / \mathrm{ml} \mathrm{FGF-4} \mathrm{caused} \mathrm{a} \mathrm{significant} \mathrm{increase} \mathrm{in}$ RUNX2 expression (Fig. 8A). 


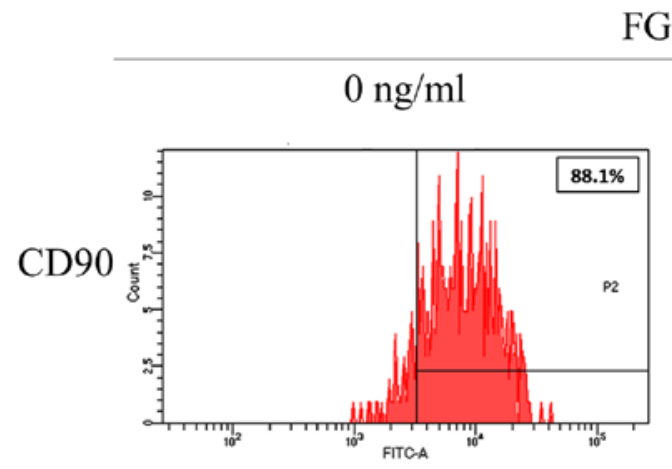

FGF-4
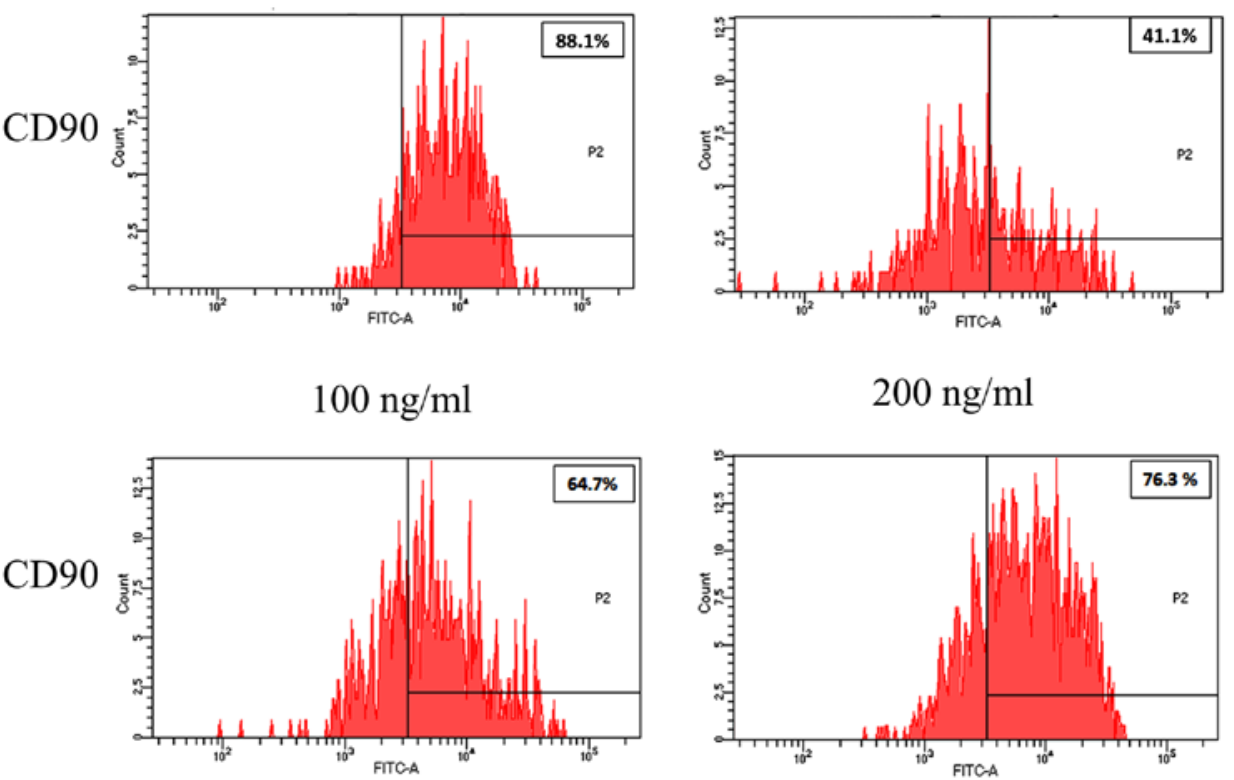

$200 \mathrm{ng} / \mathrm{ml}$

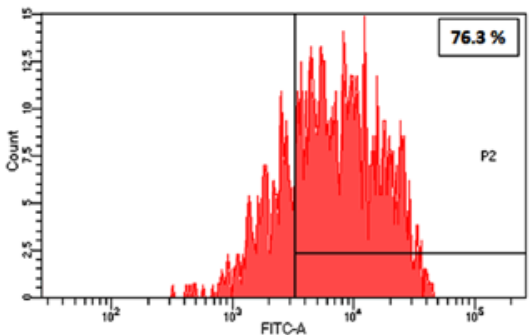

Figure 5. Evaluation of stem cell surface marker expression using CD90 cultured in growth media on day 1 . The percentages of CD90 cells were $99.0 \%$ for the untreated control $(0 \mathrm{ng} / \mathrm{ml}), 93.5 \%$ for the $50 \mathrm{ng} / \mathrm{ml}$ group, $99.1 \%$ for the $100 \mathrm{ng} / \mathrm{ml}$ group and $99.9 \%$ for the $200 \mathrm{ng} / \mathrm{ml}$ group. Groups $1-4 \mathrm{were}$ treated with fibroblast growth factor- 4 at $0,50,100$ and $200 \mathrm{ng} / \mathrm{ml}$, respectively.

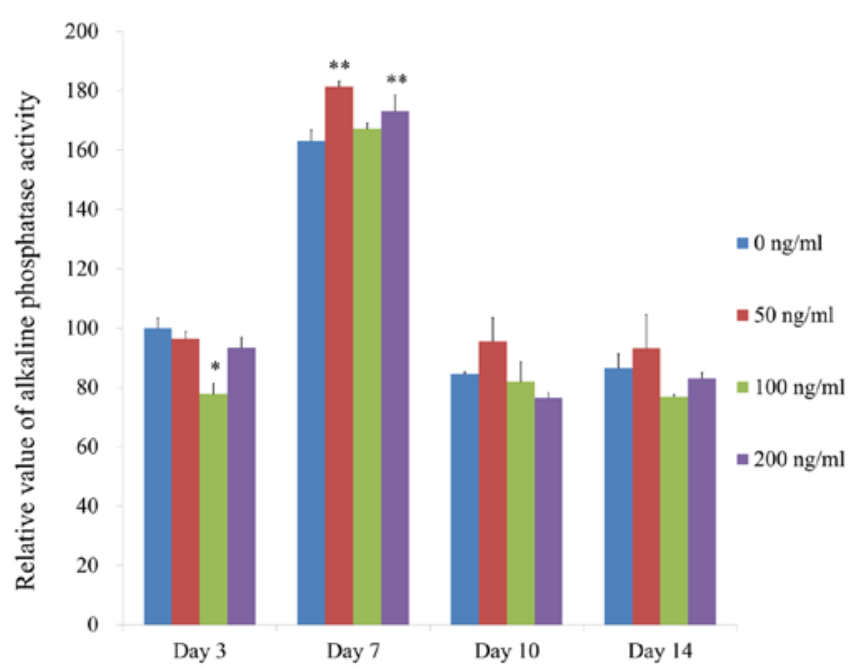

Figure 6. Alkaline phosphatase activity on days 3, 7, 10 and 14. ${ }^{*} \mathrm{P}<0.05$ vs. group 1 at day $3 .{ }^{* *} \mathrm{P}<0.05$ vs. group 1 at day 7 . Groups $1-4$ were treated with fibroblast growth factor- 4 at $0,50,100$ and $200 \mathrm{ng} / \mathrm{ml}$, respectively.

The RT-qPCR results also indicated that the mRNA expression of BGLA was 100.0 $\pm 4.8,135.6 \pm 16.6,86.8 \pm 21.2$ and $293.3 \pm 43.7 \%$ in the groups treated with FGF-4 at 0 , 50,100 and $200 \mathrm{ng} / \mathrm{ml}$, respectively. Of note, application of $200 \mathrm{ng} / \mathrm{ml} \mathrm{FGF-4} \mathrm{produced} \mathrm{a} \mathrm{significant} \mathrm{increase} \mathrm{in} \mathrm{BGLA}$ expression (Fig. 8B).

Western blot analysis was performed to detect the expression of certain proteins following treatment with FGF-4 at day 7 (Fig. 8C). The relative expressions of collagen I expression of $0,50,100$ and $200 \mathrm{ng} / \mathrm{ml}$ groups after normalization were $100.0,94.9,98.7$ and $152.1 \%$, respectively. It was indicated that the expression of collagen I increased with the addition of FGF-4. Furthermore, the relative expressions of RUNX2 expression of 0, 50, 100 and $200 \mathrm{ng} / \mathrm{ml}$ groups after normalization were $100.0,100.6,101.0$ and $118.3 \%$, respectively. Addition of FGF-4 enhanced the expression of RUNX2.

\section{Discussion}

In the present study, the effects of FGF-4 on cellular viability and osteogenic differentiation were investigated using cell spheroids of stem cells. It was indicated that the application of $200 \mathrm{ng} / \mathrm{ml} \mathrm{FGF}-4$ increased alkaline phosphatase activity and the expression levels RUNX2 and BGLA.

Mesenchymal stem cells are well-known for their pluripotent nature (25); these cells are able to differentiate into tissues of mesodermal origin, including tendons, bone, cartilage, ligaments, muscles and neurons (26). It has also been reported that mesenchymal stem cells may be isolated from human gingival tissue (17). Gingiva may be a desirable source of mesenchymal stem cell, as the harvesting procedure is relatively less invasive and tissue may be harvested during common dental treatments, including tooth extraction or gingivectomy (27). Furthermore, gingiva-derived mesenchymal stem cells grow faster than bone marrow mesenchymal stem cells and exhibit a stable morphology without losing their features of mesenchymal stem cells (28). Similar to other types of mesenchymal stem cell, gingiva-derived stem cells have demonstrated a significant osteogenic capability (29).

Mesenchymal stem cells have been reported to enhance bone regeneration by exerting auto or paracrine effects via the secretion of growth factors or direct differentiation into bone cells (30). Previous studies have revealed that mesenchymal stem cells are generally used with scaffolds $(31,32)$. Furthermore, due to its osteogenic potential, a large number of 


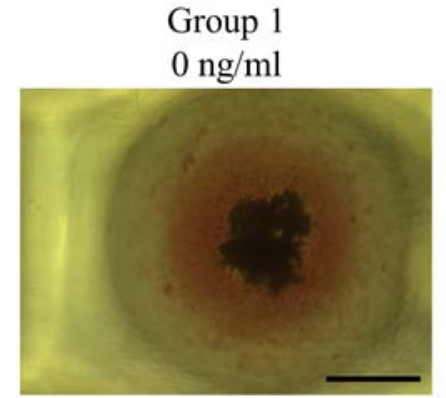

Group 3 $100 \mathrm{ng} / \mathrm{ml}$
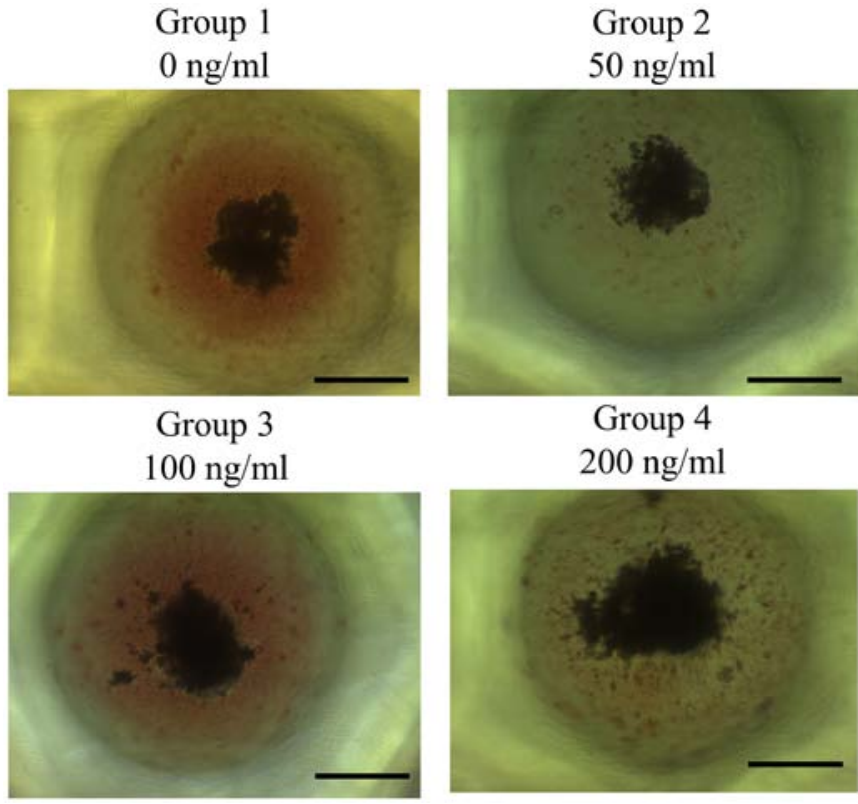

Group 4

$200 \mathrm{ng} / \mathrm{ml}$
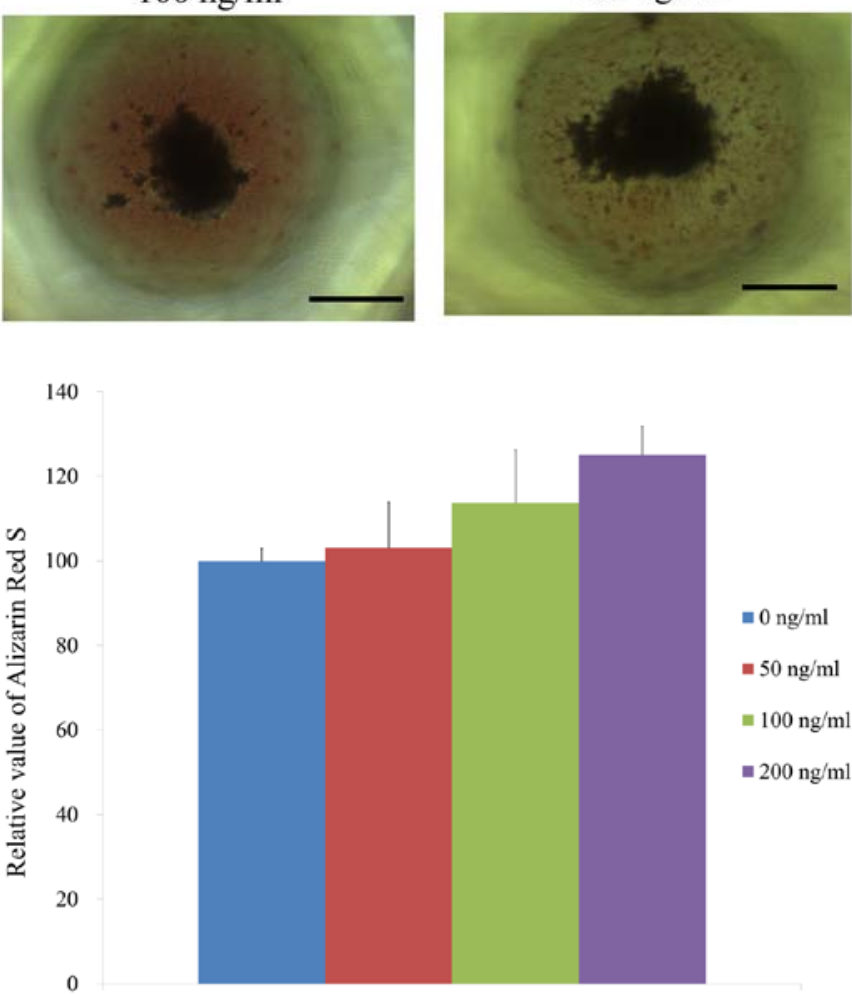

Figure 7. Results of Alizarin Red S staining at day 14. (A) Microscopic observation (scale bar, $200 \mu \mathrm{m}$ ). (B) Quantitative analysis of Alizarin Red S staining. Groups 1-4 were treated with fibroblast growth factor- 4 at $0,50,100$ and $200 \mathrm{ng} / \mathrm{ml}$, respectively.

dental studies have been performed based on the mesenchymal stem cell-loaded hydroxyapatite/ $\beta$-tricalcium phosphate scaffold $(31,33)$. If it becomes possible to ensure that the actions of mesenchymal stem cells are predictable and manageable, regeneration of alveolar bone damaged by periodontal disease may become increasingly feasible.

In recent years, 3D structures have gained increased interest (34). Cellular features on 2D in vitro cultures have been improved to mimic physiological conditions in vivo by applying $3 \mathrm{D}$ cultures (35). Furthermore, 3D cultures of adult human liver stem cells produced islet-like structures and were able to reverse hyperglycemia in mice with severe diabetes combined with immunodeficiency (34). In addition, 3D spheroid cultures allow for the fabrication of bone marrow mesenchymal cells, which retain osteogenic differentiation potential over a monolayer culture of bone marrow mesenchymal cells without the requirement to use chemicals or hormonal modulation (36). Spheroids of mesenchymal stem cells also expressed higher
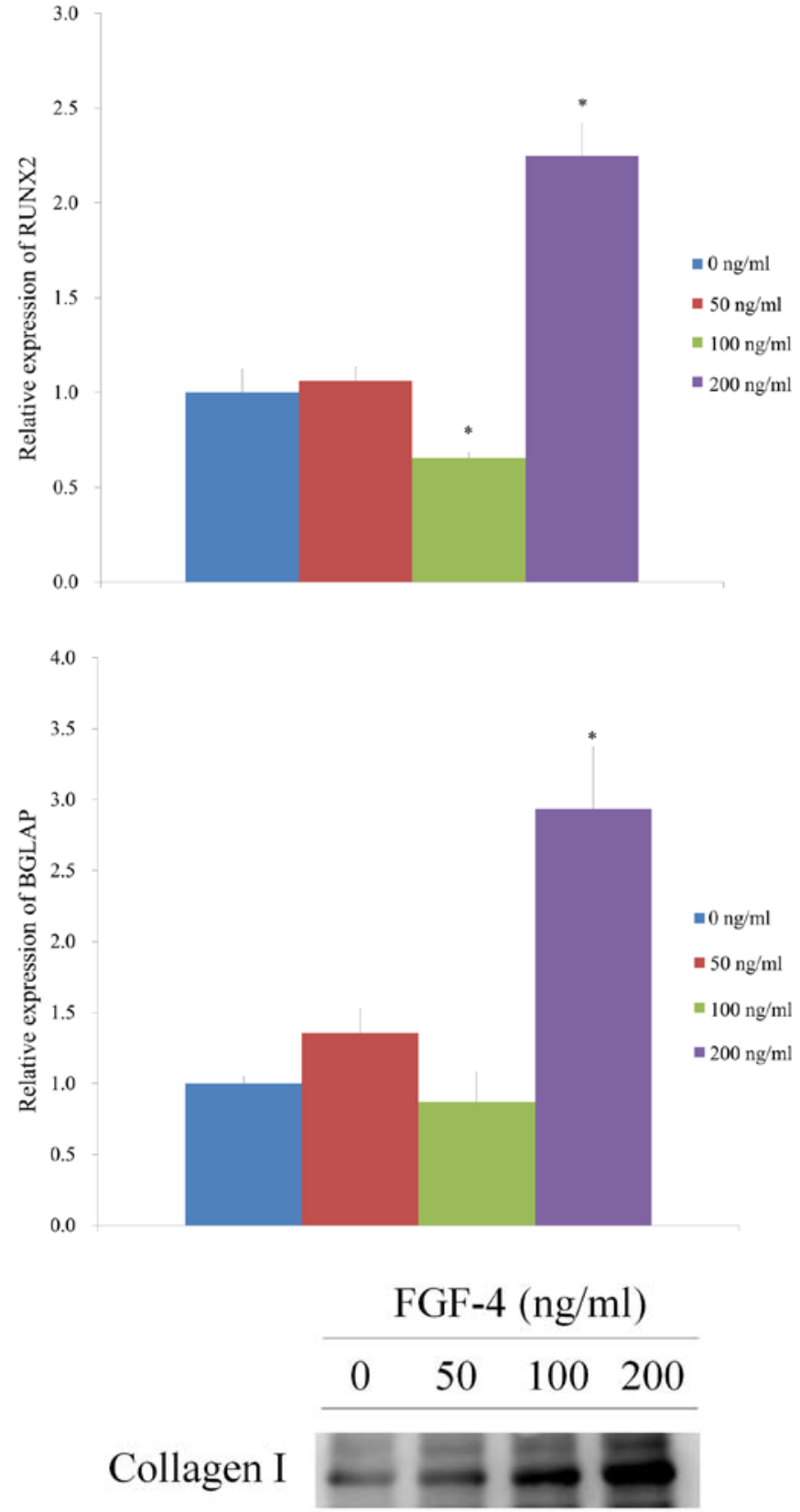

\section{RUNX2}

\section{GAPDH}

Figure 8. Reverse transcription-quantitative PCR and Western blot analysis (A) Expression of RUNX2. (B) Expression of BGLAP. (C) Western blot analysis to evaluate the expression levels of collagen I, RUNX2 and GAPDH. "P<0.05 vs. control. RUNX2, Runt-related transcription factor-2; BGLAP, bone $\gamma$-carboxyglutamate protein; FGF-4, fibroblast growth factor-4.

transcription factors that regulate stemness compared with monolayer cultures, along with higher alkaline phosphatase activity and enhanced expression of osteogenesis-associated genes (37). In another previous study, encapsulation of stem cell microspheroids was performed using gelatin-based hydrogels and it was demonstrated to have promising potential for bone or cartilage tissue engineering (38). 
The present results suggested that significant effects were achieved with 200 ng/ml FGF-4. The physiological concentration of FGFs in humans may vary but the serum concentration of FGF may be 10-100 pg/ml (39). In a previous study, FGF-4 was applied at a range of concentrations $\geq 100 \mathrm{ng} / \mathrm{ml}$ for cell culture and at $0.03,0.1$ and $0.3 \mathrm{mg} / \mathrm{kg}$ for in vivo experiments (40). In another study, FGF-4 was prepared at a concentration of $0.1 \mathrm{mg} / \mathrm{ml}$, and it was subcutaneously injected into rodent models at a dose of $0.1 \mathrm{mg} / \mathrm{kg}$ (41). Another study reported on injection of $10 \mu \mathrm{g}$ FGF-4 in an altelocollagen carrier or the carrier alone into the intended implant sites and it was revealed that a local single injection of FGF-4 stimulates bone formation around titanium implants in bone (42). Furthermore, FGF-4 produces synergistic effects in ectopic bone formation, which is induced by bone morphogenetic protein-2 (41). However, it should be noted that the optimal effective concentration of FGF-4 may differ due to differences in cell types, stage and passage of the cells, system model and duration of the culture $(24,31)$. Thus, the observations of the present study may apply only to cells on the spheroid surface, but not for cells on the inside.

The present results indicated that cellular viability was maintained in the presence of FGF-4, while osteogenic differentiation of stem cell spheroids was enhanced, at least partially by regulation of RUNX 2 and BGLAP expression. In a previous study, RUNX2 and BGLAP were selected as markers for osteogenesis (38). RUNX2 is a molecular biomarker for osteoblastic differentiation and is able to induce the expression and synthesis of BGLAP (43). Furthermore, BGLAP is considered one of the most specific markers of mature osteoblasts (22). Collagen I is considered as an osteogenic marker and induction of osteogenic supplements led to activation of collagen I expression (44). In a previous study, evaluation of mesenchymal stem cells directed toward osteogenic differentiation was performed by RNA extraction and PCR analysis of RUNX2 and BGLAP (45). However, there are limitations in the present study. The tissue was obtained from an individual of old age and this may have influenced the results (46). It appears that only the cells on the surface of the spheroids were detectable using the live/dead assay.

In conclusion, the present results suggested that the application of FGF-4 maintained cellular viability while enhancing the osteogenic differentiation of stem cell spheroids, at least partially by regulating RUNX2 and BGLAP expression levels.

\section{Acknowledgements}

We would like to thank Ms Minji Kim (College of Dentistry, Chosun University, Gwangju 61452, Republic of Korea) for performing the experiments and providing technical assistance.

\section{Funding}

This work was supported by the National Research Foundation of Korea grant funded by the Korean government (Ministry of Science and ICT; grant no. 2020R1A2C4001624). The research was also funded by the Research Fund of Seoul St. Mary's Hospital, The Catholic University of Korea (Seoul, Korea).

\section{Availability of data and materials}

The datasets used and/or analyzed during the current study are available from the corresponding author on reasonable request.

\section{Authors' contributions}

JS, JYT, SKM, YK and JBP collaborated to design the study; JS, JYT, SKM, YK and JBP were responsible for data access and analysis; JS, JYT, SKM, YK and JBP performed the experiments; JS, JYT, SKM, YK and JBP wrote the manuscript. All authors read and approved the final manuscript.

\section{Ethics approval and consent to participate}

Approval was obtained from the Institutional Review Board at Seoul St Mary's Hospital, College of Medicine, The Catholic University of Korea (approval no. KC17SESI0290). Informed consent was obtained from the participant as specified in the Declaration of Helsinki, and all of the experiments were performed according to the relevant guidelines as specified in the Declaration of Helsinki.

\section{Patient consent for publication}

Not applicable.

\section{Competing interests}

The authors declare that they have no competing interests.

\section{References}

1. Sohn B, Hwang M, Kim S, Kim HI and Ku Y: Ridge preservation using basic fibroblast growth factor- 2 and collagenated biphasic calcium phosphate in beagle dogs. J Periodontal Implant Sci 47: 381-387, 2017.

2. Tiong KH, Mah LY and Leong CO: Functional roles of fibroblast growth factor receptors (FGFRs) signaling in human cancers. Apoptosis 18: 1447-1468, 2013.

3. Nunes QM, Li Y, Sun C, Kinnunen TK and Fernig DG: Fibroblast growth factors as tissue repair and regeneration therapeutics. PeerJ 4: e1535, 2016.

4. Frese L, Dijkman PE and Hoerstrup SP: Adipose tissue-derived stem cells in regenerative medicine. Transfus Med Hemother 43: 268-274, 2016.

5. Chou YH, Pan SY, Yang CH and Lin SL: Stem cells and kidney regeneration. J Formos Med Assoc 113: 201-209, 2014.

6. Coutu DL and Galipeau J: Roles of FGF signaling in stem cell self-renewal, senescence and aging. Aging (Albany NY) 3: 920-933, 2011.

7. Boilly B, Vercoutter-Edouart AS, Hondermarck H, Nurcombe V and Le Bourhis X: FGF signals for cell proliferation and migration through different pathways. Cytokine Growth Factor Rev 11: 295-302, 2000.

8. Henry TD, Grines CL, Watkins MW, Dib N, Barbeau G, Moreadith R, Andrasfay T and Engler RL: Effects of Ad5FGF-4 in patients with angina: An analysis of pooled data from the AGENT-3 and AGENT-4 trials. J Am Coll Cardiol 50: 1038-1046, 2007.

9. Kapur NK and Rade JJ: Fibroblast growth factor 4 gene therapy for chronic ischemic heart disease. Trends Cardiovasc Med 18: 133-141, 2008.

10. Jung M, Kern FG, Jorgensen TJ, McLeskey SW, Blair OC and Dritschilo A: Fibroblast growth factor-4 enhanced G2 arrest and cell survival following ionizing radiation. Cancer Res 54: 5194-5197, 1994.

11. Quito FL, Beh J, Bashayan O, Basilico C and Basch RS: Effects of fibroblast growth factor-4 (k-FGF) on long-term cultures of human bone marrow cells. Blood 87: 1282-1291, 1996. 
12. Wu SM, Chiu HC, Chin YT, Lin HY, Chiang CY, Tu HP, Fu MM and Fu E: Effects of enamel matrix derivative on the proliferation and osteogenic differentiation of human gingival mesenchymal stem cells. Stem Cell Res Ther 5: 52, 2014.

13. Choi SC, Kim SJ, Choi JH, Park CY, Shim WJ and Lim DS: Fibroblast growth factor- 2 and -4 promote the proliferation of bone marrow mesenchymal stem cells by the activation of the PI3K-Akt and ERK1/2 signaling pathways. Stem Cells Dev 17: 725-736, 2008

14. Lee SI, Yeo SI, Kim BB, Ko Y and Park JB: Formation of size-controllable spheroids using gingiva-derived stem cells and concave microwells: Morphology and viability tests. Biomed Rep 4: 97-101, 2016.

15. Lee H, Lee SI, Ko Y and Park JB: Evaluation of the secretion and release of vascular endothelial growth factor from two-dimensional culture and three-dimensional cell spheroids formed with stem cells and osteoprecursor cells. Adv Clin Exp Med 27: 971-977, 2018.

16. Lee SI, Ko Y and Park JB: Evaluation of the maintenance of stemness, viability, and differentiation potential of gingiva-derived stem-cell spheroids. Exp Ther Med 13: 1757-1764, 2017.

17. Jin SH, Lee JE, Yun JH, Kim I, Ko Y and Park JB: Isolation and characterization of human mesenchymal stem cells from gingival connective tissue. J Periodontal Res 50: 461-467, 2015.

18. Kim BB, Tae JY, Ko Y and Park JB: Lovastatin increases the proliferation and osteoblastic differentiation of human gingiva-derived stem cells in three-dimensional cultures. Exp Ther Med 18: 3425-3430, 2019.

19. Lee H, Son J, Na CB, Yi G, Koo H and Park JB: The effects of doxorubicin-loaded liposomes on viability, stem cell surface marker expression and secretion of vascular endothelial growth factor of three-dimensional stem cell spheroids. Exp Ther Med 15: 4950-4960, 2018.

20. Huang $X$, Chen $X$, Chen H, Xu D, Lin C and Peng B Rho/Rho-associated protein kinase signaling pathway-mediated downregulation of runt-related transcription factor 2 expression promotes the differentiation of dental pulp stem cells into odontoblasts. Exp Ther Med 15: 4457-4464, 2018.

21. Lee H, Lee H, Na CB and Park JB: The effects of simvastatin on cellular viability, stemness and osteogenic differentiation using 3 -dimensional cultures of stem cells and osteoblast-like cells. Adv Clin Exp Med 28: 699-706, 2019.

22. Kaur G, Valarmathi MT, Potts JD, Jabbari E, Sabo-Attwood T and Wang Q: Regulation of osteogenic differentiation of rat bone marrow stromal cells on 2D nanorod substrates. Biomaterials 31 : $1732-1741,2010$

23. Livak KJ and Schmittgen TD: Analysis of relative gene expression data using real-time quantitative PCR and the 2(-Delta Delta C(T)) Mmethod. Methods 25: 402-408, 2001

24. Tae JY, Lee H, Lee H, Ko Y and Park JB: Osteogenic potential of cell spheroids composed of varying ratios of gingiva-derived and bone marrow stem cells using concave microwells. Exp Ther Med 16: 2287-2294, 2018.

25. Gao F, Chiu SM, Motan DA, Zhang Z, Chen L, Ji HL, Tse HF, Fu QL and Lian Q: Mesenchymal stem cells and immunomodulation: Current status and future prospects. Cell Death Dis 7 : e2062, 2016.

26. Mahla RS: Stem cells applications in regenerative medicine and disease therapeutics. Int J Cell Biol 2016: 6940283, 2016.

27. Lee H, Son J, Yi G, Koo H and Park JB: Cellular viability and osteogenic differentiation potential of human gingiva-derived stem cells in 2D culture following treatment with anionic, cationic, and neutral liposomes containing doxorubicin. Exp Ther Med 16: 4457-4462, 2018.

28. Tomar GB, Srivastava RK, Gupta N, Barhanpurkar AP, Pote ST, Jhaveri HM, Mishra GC and Wani MR: Human gingiva-derived mesenchymal stem cells are superior to bone marrow-derived mesenchymal stem cells for cell therapy in regenerative medicine. Biochem Biophys Res Commun 393: 377-383, 2010.

29. Zorin VL, Komlev VS, Zorina AI, Khromova NV, Solovieva EV Fedotov AY, Eremin II and Kopnin PB: Octacalcium phosphate ceramics combined with gingiva-derived stromal cells for engineered functional bone grafts. Biomed Mater 9: 055005, 2014
30. Futrega K, Mosaad E, Chambers K, Lott WB, Clements J and Doran MR: Bone marrow-derived stem/stromal cells (BMSC) 3D microtissues cultured in BMP-2 supplemented osteogenic induction medium are prone to adipogenesis. Cell Tissue Res 374: 541-553, 2018.

31. Kang SH, Park JB, Kim I, Lee W and Kim H: Assessment of stem cell viability in the initial healing period in rabbits with a cranial bone defect according to the type and form of scaffold. J Periodontal Implant Sci 49: 258-267, 2019.

32. Zhang ZZ, Zhang HZ and Zhang ZY: 3D printed poly( $\varepsilon$-caprolactone) scaffolds function with simvastatin-loaded poly(lactic-co-glycolic acid) microspheres to repair load-bearing segmental bone defects. Exp Ther Med 17: 79-90, 2019.

33. Vahabi S,Amirizadeh N, Shokrgozar MA,Mofeed R, Mashhadi A, Aghaloo M, Sharifi D and Jabbareh L: A comparison between the efficacy of Bio-Oss, hydroxyapatite tricalcium phosphate and combination of mesenchymal stem cells in inducing bone regeneration. Chang Gung Med J 35: 28-37, 2012.

34. Navarro-Tableros V, Gai C, Gomez Y, Giunti S, Pasquino C, Deregibus MC, Tapparo M, Pitino A, Tetta C, Brizzi MF, et al: Islet-like structures generated in vitro from adult human liver stem cells revert hyperglycemia in diabetic SCID mice. Stem Cell Rev Rep 15: 93-111, 2019.

35. Rao N, Grover GN, Vincent LG, Evans SC, Choi YS, Spencer KH, Hui EE, Engler AJ and Christman KL: A co-culture device with a tunable stiffness to understand combinatorial cell-cell and cell-matrix interactions. Integr Biol 5: 1344-1354, 2013.

36. Lawrence LM, Cottrill A, Valluri A, Marenzi G, Denning KL, Valluri J, Claudio PP and Day JB: Minimally manipulative method for the expansion of human bone marrow mesenchymal stem cells to treat osseous defects. Int J Mol Sci 20: 20, 2019.

37. Moritani Y, Usui M, Sano K, Nakazawa K, Hanatani T, Nakatomi M, Iwata T, Sato T, Ariyoshi W, Nishihara T, et al: Spheroid culture enhances osteogenic potential of periodontal ligament mesenchymal stem cells. J Periodontal Res 53: 870-882, 2018.

38. Žigon-Branc S, Markovic M, Van Hoorick J, Van Vlierberghe S, Dubruel P, Zerobin E, Baudis S and Ovsianikov A: Impact of hydrogel stiffness on differentiation of human adipose-derived stem cell microspheroids. Tissue Eng Part A 25: 1369-1380, 2019

39. Mraz M, Bartlova M, Lacinova Z, Michalsky D, Kasalicky M, Haluzikova D, Matoulek M, Dostalova I, Humenanska V and Haluzik M: Serum concentrations and tissue expression of a novel endocrine regulator fibroblast growth factor-21 in patients with type 2 diabetes and obesity. Clin Endocrinol (Oxf) 71: 369-375, 2009.

40. Kuroda S, Kasugai S, Oida S, Iimura T, Ohya K and Ohyama T: Anabolic effect of aminoterminally truncated fibroblast growth factor 4 (FGF4) on bone. Bone 25: 431-437, 1999.

41. Kubota K, Iseki S, Kuroda S, Oida S, Iimura T, Duarte WR, Ohya K, Ishikawa I and Kasugai S: Synergistic effect of fibroblast growth factor- 4 in ectopic bone formation induced by bone morphogenetic protein-2. Bone 31: 465-471, 2002.

42. Franke Stenport V, Johansson CB, Sawase T, Yamasaki Y and Oida S: FGF-4 and titanium implants: A pilot study in rabbit bone. Clin Oral Implants Res 14: 363-368, 2003.

43. Rath B, Nam J, Knobloch TJ, Lannutti JJ and Agarwal S: Compressive forces induce osteogenic gene expression in calvarial osteoblasts. J Biomech 41: 1095-1103, 2008.

44. Salasznyk RM, Williams WA, Boskey A, Batorsky A and Plopper GE: Adhesion to vitronectin and collagen I promotes osteogenic differentiation of human mesenchymal stem cells. J Biomed Biotechnol 2004: 24-34, 2004.

45. Guan M, Yao W, Liu R, Lam KS, Nolta J, Jia J, Panganiban B, Meng L, Zhou P, Shahnazari M, et al: Directing mesenchymal stem cells to bone to augment bone formation and increase bone mass. Nat Med 18: 456-462, 2012.

46. Lee H, Min SK and Park JB: Effects of demographic factors on adipogenic and chondrogenic differentiation in bone marrow-derived stem cells. Exp Ther Med 17: 3548-3554, 2019.

This work is licensed under a Creative Commons

Attribution-NonCommercial-NoDerivatives 4.0 International (CC BY-NC-ND 4.0) License. 